\title{
Students Access to Housing: A Case of Lagos State University Students - Nigeria
}

\author{
OLABISI S. YUSUFF (MRS) \\ Department of Sociology, Lagos State University, Nigeria \\ Tel: 234-703-038-6279 E-mail: soyusuf@yahoo.co.uk
}

Received: September 2, 2010

Accepted: February 15, 2011

doi:10.5539/jsd.v4n2p107

\begin{abstract}
This study looks at access to housing among the students of Lagos State University. The study employed three methods of data collection: structured questionnaires, semi-structured interviews and some case studies. The analysis of data was done by simple percentage and frequency distribution. The information gathered reveals that the past rigid frame of house-owners of denying single-girls accommodation had softened. Female students now have access to accommodation in housing market. Furthermore, information gathered indicates that most students suffer one form of discrimination or the other which include: incessant increase in house rent, domestic violence and neighours disturbances. Late arrival for lectures and non-conducive atmosphere were some of the challenges faced by students of the University. All these factors may influence negatively on students academic studies. However, it is important that the university get involved in sourcing and solving students' accommodation problem and mediating between the students and the house-owners within the communities.
\end{abstract}

Keywords: University, Students, Housing, Community Landlords/Landladies, Nigeria

\section{Introduction}

Housing is a basic human need in all societies and fundamental right of every individual. In advanced countries, housing is more accessible to all categories of people including the poor and the needy as a result of subsidies from the government. The situation is not the same in developing countries of the world. In Nigeria, for example, accessibility to housing by the poor is quite a difficult situation which is worsened by the harsh economic conditions and poor enabling environment. Likewise, accessing housing facilities by Nigerian students is no exception, especially where such university operates a non - residential policy.

In tertiary institutions worldwide, the provision of accommodation to the students' population takes different models. This includes; non-residential, where students source for their own accommodation. Residential, where the university houses all its students and dual-residential, where the university houses its student population for a period of time only, probably the first and final year, while the students during the remaining period source for their own accommodations. The experiences of students in tertiary institutions in sourcing and securing for their own accommodation around university communities are likely to be interesting and significant. Hence, this study examines the access to housing among the students of Lagos State University, Nigeria.

In 1984, Lagos State University in Nigeria was established under the leadership of Governor Lateef Jakande, as a non-residential tertiary institution. The students' population as at inception in 1984 was 341 . The students' enrolment increased from 341 in 1984 to 15,334 in 2007/2008 session (Lagos State Academic Planning Unit, 2009). This astronomical rise in students' population is likely to bring pressure on housing facilities available around the university, as most students would desire accommodation not too far from the university. The astronomical rise in students' population made the university change its original policy on hostel accommodation and had since built one block of hostel to accommodate only 200 female students. This, however, is inadequate when compared to the teeming population of the students.

Therefore, filling the gap created by shortage of housing by the university are the private developers around the university. These private developers build, fix rentage prices and let out accommodation to students. Their roles in providing accommodation to the students' population are critical and important to the students in particular and to the university in general. A reciprocal relationship is therefore created between the university and the adjoining communities through provision of housing to university students.

Generally, securing accommodation in Lagos metropolis is a Herculean task to prospective house seekers, especially women, in the category of single girls (Omoluabi, 1990). Women generally, suffer inadequate access 
to housing. Various strategies and struggles are usually adopted in order to ameliorate their hardship in accessing accommodation. Furthermore, the housing situations in Nigeria are deficient in quality and quantity (Oyebanji, 2006). There are arbitrarily and outrageous increases in house rents, a rapidly deteriorating urban environment and the sheer physical expansion of the cities (Arimah, 1997).Also the highly patriarchal nature of Nigerians, and other intervening factors are likely to pose challenges to individuals, more in the categories of students' as they source for their housing needs.

The main objective of this study, therefore, is to examine access to housing among tertiary students using of the Lagos State University as a case study. In order to address the identified problems, the following research questions underlie the focus of this study 1 , what are the different strategies employed by students in sourcing and solving their accommodation problems? 2, which of the gender do the Landlords/landladies prefer in letting out accommodation to and what are the reasons for their preference? 3, what are the forms of discriminatory practices experienced by students in solving their housing needs and how do they cope with such practices? 4, what type of relationships exists between the students - tenants and the community Landlords/Landladies 5, what are the role(s) of the University in solving student's accommodation problems? 6, what are the other challenges thrown up by the non - residential nature of the university to the students?

To achieve the stated objectives, the paper is divided into four parts. Apart from this introduction, other sections in this paper include; (2) literature review ((3) Research Methodology (4) Data Analysis and Discussions of the Findings, and implication of the study

\section{Housing Situation in Nigeria}

Nigerians are confronted with a myriad of housing problems, which are essentially connected with the hardships they face in securing and retaining a residence. This situation is particularly evident in Lagos state due to the cosmopolitan nature of the state, which has placed great demands not only on housing but also on physical and social amenities.

Egunjobi,( 1999) succinctly stated that there are twin problems of quantitative and qualitative deficiencies with respect to housing in Nigeria, especially Lagos State The efforts of governments at federal, state, and local government to provide housing for the urban population have not yielded much fruits.

Researchers have tended to draw a strategic link between urbanization processes in a country and subsisting housing problems. Thus, the rapid rate of urbanization and its attendant socio-economic and spatial consequences have been of tremendous concern to all professionals, policy makers and analysts especially as it affects urban development and management (Olatubara, 2007). It should be noted that the problem of urbanization in Nigeria is not necessarily that of level but that of rate. For example, while the level of urbanization in Nigeria is put at 36\%, that of South Korea is $79 \%$, Mexico $74 \%$ and Columbia $71 \%$ (Population Reference Bureau, 2001). While the rate of urbanization in Seoul is $7.8 \%$, Mexico City is $5.5 \%$ and Bogota $5.4 \%$ and that of Lagos is 15\% per annum (Federal Government of Nigeria, 1991).This rapidity in the rate of urbanization is so overwhelming that it generally far exceeds the speed with which government are able to respond to the dynamics of urbanization due to inadequate facilities, resources and capabilities at their disposal.

To fill the gap of quantitative housing problems in Nigeria in general and Lagos State in particular are the private developers. These private developers according to Olatubara (2008) have as their motivation the desire to make profit. Many of them capitalize on the acute shortage of accommodation by providing housing at exorbitant prices to prospective house seekers. Invariably, the majority of the houses provided by the private developers, besides being expensive are deficient in meeting the requisite minimum standards that make for a healthy and comfortable living

Also in housing policy, women or girls are often excluded or discriminated against as they do not fit into the traditional concept of a family (African Development Bank, 1990). Furthermore, Lawanson (2006) states that when housing programmes are upgrading schemes present opportunities for the improvement of human settlement, women are often excluded. Projects are designed without reference to woman's economic, domestic or community responsibilities. Policy makers focused on providing for the needs of the presumed male head of the house, virtually ignoring the large number of women who head or maintain households.

Among the perculair problems are the patriarchal attitudes of men which sees a woman who moves out of her accepted family role in order to source for accommodation, as a "loose woman". Men may fall back on societal expectations and treat the woman as sexually available. In some instances, the housing needs of women may force some of them to stay in a hostile relationship, as some may perceive that they are likely to be denied accommodation elsewhere or be sexually harassed by house-owners. 
Globally, studies had shown this trend as regards women securing accommodations on their own merits. For instance, United States Department of Justice Civil Rights Division, Housing and Civil Enforcement Section (2005) reports state that sexual harassment is more likely to occur in rental properties, and among poor women who could not afford to pay market rates in a competitive housing market. These women often choose between being harassed at home or end up living on the street. The report also revealed that many of these female-tenants sometimes were reluctant to report or challenge their landlords on their bahaviour. Instead, they move or simply put up with the harassment, as well as with poor maintenance and services rather than pursue fair treatment and justice.

Apart from this report, numbers of studies lend credence to the fact that female gender are usually discriminated against in various ways when seeking accommodation. Seager (1998), Novac (2005), Tester (2007) succinctly state that most migrant women who make up a larger proportion of international migrants are usually discriminated against especially in access to housing in foreign land. Most of these migrant women are also harassed by the landlords and their agents as a result of perceived traditional roles of women or girls.

What is certain from literature is that poor or low income women are likely to be subjected to harassment by the landlords. Likewise, female students who move out of the societal expectations of their perceived roles may equally experience sexual harassment from the landlords who may perceive them as being sexually available when trying to solve their accommodation problems.

\section{Research Hypothesis}

\section{Hypothesis}

Ho: Female students are not likely to face any form of discriminatory practices (sexual harassment) compared to their male counterparts should the university fail to provide accommodation.

\subsection{Research Methodology}

\subsubsection{Study Area}

The study site is situated within the Lagos State University and its immediate surrounding communities. Lagos State University was formally opened in 1984. The idea behind it was to provide innovative educational programmes of high standard that is relevant to the state and national development. The study site is situated in Lagos metropolis, which accommodates people of diverse ethnic groups. However, the 'Awori' ethnic group predominates in the location area. Lagos State university neighbouring communities which are included in our study area are Pipe-line Petroleum limited, otherwise known as PPL, 'Okokomaiko' and 'Iba' new site. These are the communities that adjoin the university and these are the areas where students mainly reside.

\subsubsection{Research Design}

This study is descriptive in nature. It utilized both quantitative and qualitative research method. The quantitative method consists of structured questionnaire: This consists of close-ended questions meant to elicit information on the socio-demographic characteristics of the students as well as information on students' access to housing/accommodation in LASU neighbourhood. Qualitative method consists of in-depth Interview: Interview sessions were conducted among the landlords/landladies in the communities. The questions were semi-structured. The questions were about their roles in providing accommodation to students. Case Studies: A few case studies were included as well in the study.

Probability sampling technique was adopted for the administration of the well - structured questionnaire. Since There was no data - base of the students living within the university neighbourhood. Therefore, the following probability sampling was put unto use in order to obtain a representative sample.

This researcher selected (three) 3 Faculties from all the faculties in the university by lottery methods. The faculties selected include: (a) Faculty of Management Sciences, (b) Faculty of Social Sciences and (c) Faculty of Arts. Departments in each faculty were written out and three departments were selected by lottery from each faculty. Thus we have in the Faculty of Social Sciences - Economics, Sociology and Political Science departments. From Faculty of Management Sciences, we selected through lottery - Department of Accounting and Finance, Business Administration and Banking and Finance, while in faculty of arts, the Departments of History and International Studies, Religious Studies and English were selected by lottery. In all the departments selected, compulsory courses were identified from one level to four hundred levels.

During the compulsory courses from one hundred level to four hundred levels, papers were passed to students who were living around the university community, to indicate their names and areas they reside. The students were told of the importance of the research and the need to cooperate by writing their names and the areas they 
reside. All the names in the list from one hundred level to four collected were collated. Thus from the list, we have a total number of 1,860 names. Ten percent of the students were picked from each faculty though systematic sampling technique. Thus, a total of one hundred and eighty-six questionnaires (186) were sent out to students. However, through the assistance of two research assistants, we were able to retrieve one hundred and sixty-four questionnaires (164).

For the graduands, they were purposively picked irrespective of the year of graduation. The total number of the graduands was twenty-six (26). In all, we have a total number of one hundred and ninety (190) respondents.

The fifteen Landlords/Landladies included in the study were picked through Multi-Stage Sampling Technique in the community. We solicited for the cooperation of the landlords/landladies by explaining to them the importance of the research.

\section{Data Analysis/Critical Discussions}

The data generated from the survey was analysed using simple-percentage and chi-square to test the hypothesis. The content analysis of the qualitative data was also done. Quotations from respondents were recorded verbatim. The interview was done in English.

\subsection{Socio-Demographic Characteristics of the Respondents}

Socio-demographic characteristics of the respondents gathered on gender differentials in access to accommodation revealed that $55.3 \%$ were female, while male represented $44.7 \%$ of the sampled population. Among the respondents, $32.6 \%$ of the respondents resided in Petroleum - pipeline Limited area - otherwise known as PPL; $26.86 \%$ resided in Okokomaiko, while (40.5\%) resided in Iba new town. The implication of this was that many students were able to secure accommodation at Iba new site. From direct observations, it should be stated that of recent, more buildings were under construction by private owners at Iba new - town. This probably may be as a result of the presence of Lagos State University.

Distribution by faculty from the table shows that $41.6 \%$ of the students were from faculty of Management Sciences, while $37.9 \%$ were from Social Sciences. $18.4 \%$ represented those in the faculty of Arts. Others were represented by $2.1 \%$. This implies that a majority of the sampled respondents were from the faculty of management sciences. The table also revealed the age - distributions of the respondents. Those in the age group $18-24$ yrs constituted $13.2 \%$, age - group $25-30 \mathrm{yrs} 60.5 \%$. This shows that majority of the respondents were in age group of 25-30 years

\subsection{Strategies Employed By Students in Sourcing and Solving Accommodation Needs}

We seek to examine the strategies that are likely to be adopted by students in securing their accommodation needs. Majority of graduands, $(73 \%)$ secured their accommodation from the landlords/landladies and transfer from students. For the intermediate and new students, registered agents and landlords/landladies were the major strategies used to source for their accommodation needs. This implies that landlords/landladies were involved in the business of directly renting out accommodation to students on their own. The presence of registered agents was a new phenomenon among the student. The "registered" agents on their own, source for the rooms/flats and compile all the list of houses available around the university. Students were charged N500 (Five Hundred Naira) by the agents before information on available houses for rent can be obtained. If agreement is reached between the student, the landlord, and the registered agent, the agent gets his own commission in monetary terms. This means that Lagos State University through its students had created employment opportunities for some categories of people in the neighbourhood.

$46.2 \%$ of students solved their accommodation problems through fellow students. Students either sub-let or transfer their apartments to other students upon the completion of their studies. These new tenants were usually presented to the landlords/landladies either as brothers or sisters or friends who had shown interest in the apartment. In these cases, agents are by-passed, making the rent cheaper as the new tenant may not really consummate a fresh agreement, which attracts a large sum of amount. This is one of the strategies adopted by the students in trying to cut cost and solve their accommodation needs.

On gender analysis of the strategies used by students to solve their accommodation problems, the data revealed that a majority of female students in all categories (55.2\%) secured their accommodation directly from the landlords/landladies while among the male students (44.8\%) registered agents were the major strategy utilized. In Nigeria as well as other developing countries, securing accommodation is either through the landlords/landladies or registered agents. It is interesting to ask how female students secured accommodation in the neighbourhood through the landlords/landladies considering the societal perception of female gender and the age long tradition of not letting out accommodation to single-girls. 


\subsection{Landlords/Landladies Preference}

Information gathered from the student's respondents revealed that landlords/landladies preferred female students to male students. In the past, preference was given to the male-students. A total percentage of $(61.5 \%)$ representing more male students (Graduands) secured accommodation from landlords. However, among the returning students $(67 \%)$ it was observed that landlords preferred female students to male students. What then are the reason(s) behind the change of preference from male students to female students?

In an in-depth interview with fifteen landlords/landladies on which gender they prefer to let out accommodation to, 12 of them $(80 \%)$ indicated female students while only 3 representing $(20 \%)$ indicated male students. The common expressions/ statements among the thirteen (13) landlords/landladies that favoured female students were that:

"Male students were troublesome. They engaged in cultism and robbery. Male students do not keep to the terms of agreement in the house. In fact, Male students upon graduating from the university sometimes refuse to vacate their rooms, unless they were forced to.

While the three (3) of the Landlords/Landladies that favoured male students commented on female students that "They believe they may be of bad influence to their children because of their life styles". And among those in favour of female students, the common expressions were that

"Female - students keep to the terms of agreement. They are good house - keepers and they hardly cause any trouble in the house. They usually come out during monthly environmental sanitation".

These perceptions are still in line with the traditional roles of women. Going by the views expressed by the landlords/landladies, it is pertinent to ask whether the traditional idea of renting out accommodation only to male in the society is changing. One would have thought that there is a paradigm shift from traditional values about who gets accommodation from the landlords/landladies. But following in-depth interviews with the landlords/landladies, ten of them who prefer female to male students gave the same responses

"We cannot give our rooms/flats to single girls. They have to come to us with their parents, brothers or their uncles who were expected to be in contact with us from time - time or if there is no one to come with, they will report to "Bale of the area who will turn give them letter of introduction to us".

The information revealed that though their preference may change, but the traditional beliefs about giving out accommodation to single girls had not changed. The above findings corroborated a response reported in Olurode (1990) when a lady commented to him that "do you know that I had to tell my landlord that I was engaged before he agreed to rent out my flat to me". This statement is still largely a confirmation that our society is patriarchal in nature. Milimo (1984) cited in Olatubara (2008) stated succinctly that patriarchy as a factor is strong enough to keep women in perpetual subjection. After securing accommodation from landlords /landladies, do female students face any form of discriminatory practices? The next section discusses the responses.

\subsection{Gender Experiences of Discriminatory Practices}

Discrimination is to make unfair differences in one's treatment of people. People may be unfairly treated for reasons of their sex, race, and tribe or even for reasons of their beliefs. Housing discrimination is a serious problem because it is difficult to challenge or prove. Majority (65\%) of the female students of the total sampled respondents had experienced one form of discrimination or the other. While $35.3 \%$ of the male respondents had it before. $33.5 \%$ of the female had not experienced any form of discrimination while $64.7 \%$ of the male belong here.

Questions were asked about the types of discriminatory practices that had been experienced. Among the graduands, $27 \%$ of the female students commented that religion and gender biases were the major forms of discriminatory practices experienced, while $41 \%$ of returning and fresher's female students mentioned sexual harassment as the major form of discriminatory practice. Sexual harassment according to Akande (1999) is seen to affect negatively the environment in which the offender and victim interact, either at work or in a social context. Sexual harassment pollutes the working environment and can have a devastating effect upon the health, confidence, morals and performances of those affected by it. Though, there are no national statistics on sexual harassment in access to housing, sexual harassment includes a broad range of landlords' misbehaviours which include: making comments, touching, entering home to watch women while they sleep or shower, exchanging sex for rent or repairs, sexual assault and rape.

A four hundred level female student recalled her experiences with her landlord; 
"When my friend left for another place because of religious differences between us, my land lord called me and said I too should move out or we should be having sexual intercourse together. He was touching me aggressively. The pressure on me was so much that I had to pack to another place.

What is certain is that there is imbalance of power relationships between landlords and student tenants. Most landlords exercise this power unjustly on students where such student refuses to cooperate. Hostility also may likely set in. Most students do not even know whom to tell of their predicaments. That was the reason why all the female students (the graduands, returning and freshers) responded to instances of discrimination by searching for alternative accommodation. This finding was also in line with the report stated in United States Department of Justice Civil Rights Division, Housing and Civil Enforcement Section (2005). On the other hand, students who are vulnerable and succumb to pressure from landlords sexual advances are at the risk of reproductive health bahaviour (Wusu, 2010). However, while it is necessary to maintain good relationship with one's landlord, such relationships must be formal. Female students need to have a well-balanced self-esteem. Their sense of dressing must be proper, as improper dressing sends wrong signal to male counterparts, even to the landlord.

Another major discriminatory practice experienced by students was differential rent charges. Female students (the freshers) complained of discriminatory rent charges. Students were made to pay series of money by the agents before rooms can be allocated to them. For instance, students were made to pay for a year's electricity bill, damages and water rates. A practice that was not common in Nigeria. One could state that the money culture had caught up with the landlords/landladies. They behave as shylock. The presence of students from the Lagos State University coupled with inadequate housing had been the driving force behind this money culture. While the landlords/landladies often smile to the banks, students were paying through their nose to get accommodation. A group of people who live on rents has emerged.

In an in-depth interview with a landlord, it was revealed that a prospective student pays a total amount of sixty-eight thousand naira for a room apartment in a "face-me-I-face-you" dwelling (see picture 1 in the Appendix). A room costs two thousand naira per month. A prospective student tenant pays for two years which amounts to forty-eight thousand naira $(48,000.00)$. In addition, another twenty thousand naira is paid as commission and agreement fees. For a room in a flat which costs $(4,000.00)$ per month, an advance payment of two years is paid which amounts to Ninety six thousand naira only $(96,000.00)$. Another twenty thousand is paid for the agreement and commission. Therefore, a room in a flat cost a total amount of one hundred and sixteen thousand naira for two years. However, when we compare the amount charged for a room and the quality of facilities provided for the tenants (see picture 2 and 5 in the Appendix for the type of shared kitchen and toilet). It is obvious that the house owners are concerned more with profit than making life comfortable for people (Oduwade, 2000).

Below is the breakdown of amount students pay to secure accommodation around the university communities

For a room apartment $-48,000=00$ (Forty - eight thousand naira) is charged for two years.

$20,000=00 \mathrm{~N}$ (Twenty thousand Naira) is charged for commission.

$10,000=00 \mathrm{~N}$ (Ten Thousand Naira) is charged for damages, while, $10,000=00$ (ten thousand Naira is charged for electricity bill for a year.

When compare to the minimum wage in Nigeria, it could be inferred that larger percentage of income given to students by parents had gone in securing accommodation.

When this researcher asked if the university should take all its students away from the community, the responses emanated from all the landlords/landladies was NO.

The common statement was:

"We prefer to let out our rooms to students. In fact, we normally reserve our rooms for them. We feel their impact whenever they are on vacation. The prices of goods like edibles, provisions, detergents and all other household-uses normally go down because we sell mostly to students".

It could be inferred from their responses' that the Lagos State University through its students was contributing to the local economy and impacting positively on its neighbour's economic status. However, on the part of the student, when we compare what they pay as house-rents to their socio-economic background and the cost of transportation to and from university, it probably might not give the students money to spend in other areas like buying of text-books, eating balance diet, access to computers, photocopying, typing of assignment, and all other things that make for good academic success. Others may even engage in risky reproductive health behaviour in order to survive (especially the female students). All these would have negative effects on the students and may 
make university life unenjoyable. Furthermore, apart from paying exorbitant prices before securing accommodation, maintaining good relationship is equally pertinent. What then is the relationship between the students and the landlords/landladies?

\subsection{Students/Landlords Relationships}

Questions were asked about students relationships with their landlords/landladies. The aim was to ascertain the state of their relationships between them as this is important for their well-being, their state of mind and effective concentration in their studies. Among the students population, male-students (48.2\%) had cordial relationship with their landlords/landladies; $17.1 \%$ of the female respondents had cordial relationship with the landlords/landladies, while $54.3 \%$ of female respondents and $34.1 \%$ of male students had conflictual relationships with their landlord/landladies; $17.1 \%$ of female students and $10.67 \%$ of male respondents expressed attitudes of indifference.

Students' attitudes of indifference to conflict with their landlords/landladies might have developed as a result of physical and mental disturbances they experienced at home. $45.9 \%$ of male population expressed neighbours disturbances as the major form of disturbance experienced. Neighbours' disturbances could occur in varying forms. Such as noise pollution coming from generating set, untidy premises or anti-social behaviours of the co-tenants.

Mr. X, a four hundred level student had this to say:

"There were forty-eight rooms in our house. Most of the tenants were traders with large families. Their children disturbed a lot. Co-tenants put on their generating set from night till early hour of the next day. Apart from this, whenever I come back from the school, I always meet the frontage of my room very dirty".

Noise pollution caused by neighbours was a common occurrence in "face-me-I-face-you" dwellings. Radio, TV sets and musical sets are often very loud. There are also noises and beating of drums and clapping of hands from religious houses that have proliferated the society over the years. Neighbours sometimes do not exercise restraint in disturbing other tenants. Noise pollution can cause mental disturbance to the students. Mentally, students are overstretched with school workloads. The time to relax at home is usually hindered by various activities that cause noise pollution that may impact negatively on students academic performances and good health.

Domestic violence constituted another major form of disturbance at home. $32.4 \%$ of female respondents and $37.6 \%$ of male respondents had expressed this disturbance. Domestic violence usually occurs as a result of sharing facilities together like kitchen, toilet or bathroom.

According to the same Mr. X - a four hundred level student:

"There were only two bathrooms for the whole of forty-eight rooms occupants but only one was in good shape. I had to wake up very early around 5am to take my bath otherwise the queue I would meet at the front of the bathroom would make me run back". (See picture in the Appendix)

Arbitrary increase in house-rent also constituted another major source of anxiety that some of the female students faced. $17.1 \%$ of the female respondents expressed this disturbance while male respondents did not indicate this. Olatubara (2008), states that one of the major housing problems confronting Nigerians is the arbitrary and outrageous increase in house-rents. Landlords justify their actions on the basis of the ever-increasing cost of building materials and goods.

Incidence of robbery was another major disturbance faced by the students. $23.4 \%$ of female respondents and $31 \%$ of male respondents stated incidence of robbery at home as a major disturbance.

Miss Y stated: "I had been attacked twice by robbers in the area where I stayed".

What then are the roles of the university in seeing to the welfare of its students living in the neighbourhood?

\subsection{The Role(S) of the Lagos State University in Solving Students Accommodation Problem}

At the inception of the university, even as a non-residential university, studies had documented the roles of university in sourcing, settling grievances and solving other accommodation problems of the students (Lagos State University Press, 1996).

However, from the data generated $55.3 \%$ of female respondents and $44.7 \%$ of male respondents expressed their opinions that the university was not playing any role either in sourcing, securing accommodation, and settling grievances in their various apartments. .

In an in-depth interview with the university officer in charge of students' welfare, the officer could not state when the university actually stopped being involved in solving students' accommodation problems. He says: 
"We (university) are not directly involved in student accommodation problems. We are only concerned with the female hostel inside the campus. However, if there is any case brought to us, we will settle it".

He however, mentioned that of recent, a female student came to complain about her landlord. The landlord was invited and the grievance was settled. However, the officer did not disclose the nature of the grievance.

\subsection{Challenges Faced as a Student in a Non-Residential University}

Students in a non-residential university are likely to face a lot of challenges as they journey to and from the university. Considering the nature of housing facilities in Lagos as already espoused in this study and the traffic congestion on the Lagos-Badagry expressway, what then are the challenges faced? Lack of conducive atmosphere for studying was the major challenge faced by female students $(36.3 \%)$ and male students $(22.6 \%)$.

One of the respondents (Mr. X) has this to say about the situation:

"When the situation in my house was getting worse. In my part three, challenges at the university were getting tougher. I had to change accommodation because I need a conducive atmosphere for studying".

Students reside in houses where other tenants engage in all sort of unrelated economic activities. These economic activities may be a sort of distraction to proper academic studies (see picture 4 in the Appendix). We also see in picture 1 one of the students sweating while studying. The sweating was as a result of poorly ventilated room.

Lateness to lectures was also a common occurrence among some students: $(12.6 \%)$ of female students and $(14.7 \%)$ of male students expressed this as a major challenge they faced as non-residential university students.

Mr. Y stated:

Sometimes, because of inadequate transportation coupled with traffic congestion on the road, we had to trek some kilometers before we reach the campus.

\section{Conclusions/Implication of Study}

This study was interested in examining the relationship between gender and access to housing among students of the Lagos State University. Specifically, it sought to examine the strategies and forms of discriminatory practices experienced by female students in sourcing and solving their accommodation problems. It was also interested in finding out the types of reciprocal relationships existing between students-tenants and community landlords/landladies. The study also examined the role(s) of the university in sourcing and solving students' accommodation problems. Lastly, the challenges being faced by students were examined.

The proposition of this study states that gender of a student will affect access to housing and will also determine the types of discriminatory practices that will be experienced. To some extent this was so, but it was noticed that previous rigid frame has given way to a more flexible attitude regarding the landlords/landladies' attitudes to female tenants in the housing markets. Female students are strategizing to resist unfair treatment and forms of discriminatory practices directed at them for reasons of their gender. Feminist theorists advocate a continuous struggle by women in fighting oppression in whatever way it expresses itself.

The study hypothesized that where a university fails to provide students' accommodation, female students in trying to secure and solve accommodation problems often experience sexual harassment from the landlords. The study found empirical support for this hypothesis. It was found that a significant level of female students had experienced sexual harassment from the landlords. This was a confirmation of the report of a research carried out by a human rights group on housing in the United Nations. The report states that:

The victims of landlord-tenant sexual harassment were most often women in the most desperate circumstance, while many of them are extremely vulnerable.

It was revealed that female gender secured their accommodation directly from the landlord/landladies. Though the landlords/landladies did not give them the accommodation based on their own merit, the presence of their parents/guardian was required before accommodation can be given out for securing the accommodation. This goes a long-way to show that Nigerians are still patriarchal in nature.

Registered agents were utilized by both gender, but mostly by male students. The study also revealed that landlords/landladies preferred female students to male students. There were lots of reasons behind their preference. These include: economic motive, fear of cultism by male students and ability of female students keeping to the terms of agreement more than male students.

This study also found a significant relationship between gender and expressions of forms of discriminatory practices. Female students mentioned religion, gender bias and sexual harassment and discriminatory rent charges, as the major forms of expressions of discriminatory practices they had experienced. 
This study revealed that the relationship between student-tenants and landlord was cordial to some extent, but a significant level was conflictual. The conflictual relationship was partly due to these discriminatory practices they had experienced. Male and female students experienced mental disturbances in their 'hostels'. These mental disturbances include, neighbour disturbances, domestic violence and incessant increase in house-rent.

As regards the role of the university in solving students accommodation problems, the information collected indicated that the university was not involved in anyway in sourcing or solving their accommodation problems. This finding was also supported by the officer in charge of students' welfare in the university. However, the university was not totally passive about the plight of the students living in the community as any matter on accommodation brought to its notice would receive adequate attention. Lastly, lack of conducive atmosphere for studying and late arrival for lectures was the major challenge faced by students in rented apartments.

Based on the above findings - we concluded that there was a reciprocal impact between the community landlords/landladies and Lagos State University. Lagos State University was contributing to the local economy through students' spending alone. Jobs were created for some category of people (i.e. the registered agents) in the community. The university would do well to formalize this potential and incipient reciprocal outlook so that students' interests could be better protected. In view of the foregoing, therefore, the following recommendations are therefore being suggested:

There is need for the university to ameliorate students' accommodation hardships;

The university may do well by sourcing for buildings in the communities which can be taken on behalf of the students as students' hostel.

University, through the 'Bale' and landlords/landladies associations may get the house-owners registered with the University with the aim of acting as proxy between the students and the house-owners. While incoming students should be encouraged to seek accommodation from registered house-owners with the university.

It is also important for the university to inspect quality of facilities available in these houses that are registered by house-owners.

The issue of sexual harassment of female students by the landlords needs to be examined. More education is needed for the students especially the incoming students during orientation. It is pertinent even as of now to have a forum where students can come and complain of their grievances. All students in the university must be adequately informed of such forum. Landlords also need some sensitization in this regard.

University intervention is required in terms of provision of shuttle buses that would be placed at strategic locations within the community and mainly for students use. This would address the problems of students' late arrival for lectures.However, it is not visible for the university to accommodate all its students. To remove them from the local society is to shut and disconnect the relationship between gown and the town. University needs to create serious awareness about civic relationship in students. By virtue of their living method in the community, students are expected to have a better appreciation of the plight of ordinary poor Nigerians. These experiences should activate the students' sense of civic participation in the affairs of the community as a means of adding value to the community life. There cannot be a better form of reciprocal relationship between the university and its neighbouring communities.

\section{Hypothesis}

Ho: Female students are not likely to face any form of discriminatory practices (sexual harassment) compared to their male counterparts should the university fail to provide accommodation.

Method of hypothesis testing adopted - chi-square method.

Formula:

$\mathrm{X}^{2}=(\underline{\mathrm{o}-\mathrm{e}})^{2}$

$\mathrm{e}$

Degree of freedom (critical value) (C-1) (R-1)

From the calculation, chi-square value $\mathrm{x}_{\text {cal }}^{2}=64.7$

While the critical value $\mathrm{x}_{\text {tab }}^{2}=9.87$

Since $x_{\text {cal }}^{2}$ value $\left.(64.7)>\right)\left(\right.$ tab value $(9.87)$ therefore the null hypothesis is rejected and alternative hypothesis $\left(H_{a}\right)$ is accepted which states that female students are likely to face discriminatory practices (sexual harassment) compared to their male counterparts. 


\section{References}

African Development Bank. (1990). African Development Fund: Policy Paper on Women in Development. Paper Presented in Joint Sessions held in Abidjan from 17-18 September, 1990.

Akande, J. (1999). Miscellany at Law and Gender Relations, MU Professional Publishers Limited, Lagos.

Arimah,B.C. (1997). 'Some Determinants of Housing Deterioration in an African city' The case of Ibadan, Nigeria. Journal of Real Estate and Construction. Vol 7.Pp 19-37

Egunjobi, L. (1999). Our Gasping Cities: An Inaugural Lecture, University of Ibadan, Nigeria.

Federal Government of Nigeria. (1991). The National Housing Policy in Nigeria.

Lagos State Academic Planning Unit. (2009). Lagos State University Press

Lagos State University. (1996). Lagos State University Press.

Lawanson, J.O. (2006). Gender Differentials in Nigeria: Implications for Sustainable Urban Development. www.unilag.edu/ng/publication/opendoc.php?

Milimo, M.C. (1987). Women Population and Food in Africa: The Zambia Case. Development: Seeds of Change, Vol. 2, No. 3. In Olatubara, C.O. (2008). The Dynamics of Households Residential Choice in Nigeria - The Fifteen Faculty Lecture, FSS, U.I, Ibadan.

Novac S. (2007). Immigrant Enclaves and Residential Segregation: Voices of Racial Zed Refugee and Immigrant Women. [Online] Available: www.hnc.utoronto.ca/publish/women-pdf

Oduwade, L. (2000). Housing the Urban Poor: A Study on Alaba and Ipanri Low Cost Housing Estate, Surulere, Lagos in Odumosu et al (eds.) Social Problems and Social Work in Nigeria. Centre for Planning Studies, Lagos State University.

Olatubara, C.O. (2008). The Dynamics of Households Residential Choice in Nigeria - The Fifteen Faculty Lecture. Faculty of Social Sciences, University of Ibadan.

Olurode, Lai. (1990). Women, Social Change and Perception of Gender Roles in Lai Olurode (ed.). Women and Social Change in Nigeria. Unity Publishing Research Co. Ltd., Lagos State Nigeria.

Oyebanji, A.O. (2006). Housing Management in Nigeria: A challenge to BUMPAN in a Deregulated Economy. Journal of Estate Survey Research. Vol 1(2). Pp 10-32

Population Reference Bureau. (2001). 2001 World PopulationData Sheet.PRB, Washington.D.C.

Seager, J. (1996). Women in the World: An International Atlas, Simon and S. Cluster, Inc. New York.

Tester, G.N. (2007). The Relational and States Foundation of Gender Discrimination in Housing. www.ohiolink.edu/ctd/vies.

United State Department of Civil Rights Division Housing and Civil Enforcement Section. (2005). www.usdoj.gov/crt/housing/caselist_htmn\#gender

Wusu,O. (2010). Reproductive Health issues Among Undergraduate in Lai Olurode (ed)- Reciprocal Impact: A study of LASU and its Neighbours. Department of Sociology, Lagos State University, Ojo-Lagos, Nigeria. 
Table 4.1.1 Demographic Characteristics of the Respondents

\begin{tabular}{|c|c|c|c|}
\hline Statement & Variables & Frequency & Percentage \\
\hline \multirow[t]{3}{*}{ Gender } & Male & 85 & 44.7 \\
\hline & Female & 105 & 55.3 \\
\hline & Total & 190 & 100 \\
\hline \multirow[t]{4}{*}{ Place of Residence } & PPL & 62 & 32.6 \\
\hline & Okokomaiko & 51 & 26.9 \\
\hline & Iba New Site & 77 & 40.5 \\
\hline & Total & 190 & 100 \\
\hline \multirow[t]{5}{*}{ Faculty } & Management Science & 79 & 41.6 \\
\hline & Social Sciences & 72 & 37.9 \\
\hline & Arts & 35 & 18.4 \\
\hline & Others & 4 & 2.1 \\
\hline & Total & 190 & 100 \\
\hline \multirow[t]{4}{*}{ Age Group } & $18-25$ years & 25 & 13.2 \\
\hline & $25-30$ years & 115 & 60.5 \\
\hline & Others & 50 & 26.3 \\
\hline & Total & 190 & 100 \\
\hline
\end{tabular}

Source-field work -2009

Table 4.1.2 Strategies Employed by Students in Sourcing for Accommodation

\begin{tabular}{|l|c|c|c|c|c|}
\hline \multicolumn{1}{|c|}{ Variable } & Variable & Old & Inter & New & Total \\
\hline \multirow{2}{*}{ Registered Agents } & Female & $1(0.5)$ & $22(11.6)$ & $11(5.8)$ & $34(17.9)$ \\
\cline { 2 - 6 } & Male & $2(1.1)$ & $18(9.5)$ & $18(9.5)$ & $38(20)$ \\
\hline \multirow{3}{*}{ Landlord/Landladies } & Female & $8(4.2)$ & $28(14.4)$ & $22(11.6)$ & $58(30.5)$ \\
\cline { 2 - 6 } & Male & $3(1.6)$ & $12(6.3)$ & $5(2.6)$ & $20(10.5)$ \\
\hline \multirow{2}{*}{ Transfer from Students } & Female & $6(3.2)$ & $4(2.1)$ & $8(4.2)$ & $18(9.5)$ \\
\cline { 2 - 6 } & Male & $5(2.6)$ & $10(5.3)$ & $6(3.2)$ & $21(11.1)$ \\
\hline None of the above & Female & - & - & - & - \\
\cline { 2 - 6 } & Male & - & - & - & - \\
\hline Total & Female & - & - & - & - \\
\cline { 2 - 6 } & Male & - & - & - & - \\
\hline
\end{tabular}

4.1.3. Landlords/Landladies Preference

\begin{tabular}{|c|c|c|c|c|c|}
\hline Variable & Variable & Old & Inter & New & Total \\
\hline \multirow{3}{*}{ Female Students } & Female & - & $38(20)$ & $28(14.7)$ & $66(34.7)$ \\
\cline { 2 - 6 } & Male & $2(1.1)$ & $14(7.3)$ & $20(10.5)$ & $36(18.9)$ \\
\hline Male Students & Female & $8(4.2)$ & $14(7.3)$ & $8(4.2)$ & $30(15.8)$ \\
\cline { 2 - 6 } & Male & $10(5.3)$ & $13(6.8)$ & $4(2.1)$ & $27(14.2)$ \\
\hline All of the above & Female & $2(1.1)$ & $8(4.2)$ & $3(1.6)$ & $13(6.8)$ \\
\cline { 2 - 6 } & Male & $4(2.1)$ & $2(1.1)$ & $4(2.1)$ & $10(5.3)$ \\
\hline I don't know & Female & - & $3(1.6)$ & $2(1.1)$ & $5(2.6)$ \\
\cline { 2 - 6 } & Male & - & $2(1.1)$ & $1(0.5)$ & $3(1.6)$ \\
\hline Total & & $\mathbf{2 6 ( 1 3 . 7 )}$ & $\mathbf{9 4}(\mathbf{4 9 . 5 )}$ & $\mathbf{7 0 ~ ( 3 6 . 8 )}$ & $\mathbf{1 9 0}(\mathbf{1 0 0})$ \\
\hline
\end{tabular}


Table 4.1.4. Those that had Experienced Discriminatory Practices

\begin{tabular}{|c|c|c|c|c|c|}
\hline Variable & Variable & Old & Inter & New & Total \\
\hline \multirow[t]{2}{*}{ Yes } & Female & $10(5.3)$ & 34 (17.9) & $26(13.7)$ & $70(36.8)$ \\
\hline & Male & $2(1.1)$ & $10(5.3)$ & $18(9.5)$ & $30(15.8)$ \\
\hline \multirow[t]{2}{*}{ No } & Female & - & $10(5.3)$ & $7(3.7)$ & $17(8.9)$ \\
\hline & Male & $14(7.4)$ & $15(7.9)$ & $6(3.2)$ & $35(18.4)$ \\
\hline \multirow[t]{2}{*}{ I don't know } & Female & - & $10(5.3)$ & $8(4.2)$ & $18(9.5)$ \\
\hline & Male & - & $15(7.9)$ & $5(2.6)$ & $20(10.5)$ \\
\hline Total & & $26(13.7)$ & 94 (49.5) & $70(36.8)$ & $190(100)$ \\
\hline
\end{tabular}

Table 4.1.5. Forms of Discriminatory Practices Experienced

\begin{tabular}{|c|c|c|c|c|c|}
\hline Statement & Variable & Old & Inter & New & Total \\
\hline \multirow[t]{2}{*}{ Finance } & Female & - & - & $8(4.2)$ & $8(4.2)$ \\
\hline & Male & $2(1.1)$ & $10(5.3)$ & $12(6.3)$ & $24(12.6)$ \\
\hline \multirow[t]{2}{*}{ Sexual Harassment } & Female & - & 25 & $18(9.5)$ & 43 \\
\hline & Male & - & - & - & - \\
\hline \multirow[t]{2}{*}{ Religious Bias } & Female & $3(1.6)$ & $7(3.7)$ & - & $10(5.3)$ \\
\hline & Male & - & - & - & - \\
\hline \multirow{2}{*}{ Gender Bias } & Female & $7(3.7)$ & $2(1.1)$ & - & $9(4.7)$ \\
\hline & Male & - & - & $6(3.2)$ & $6(3.2)$ \\
\hline \multirow[t]{2}{*}{ No Discrimination } & Female & - & $10(5.3)$ & $7(3.7)$ & $17(8.9)$ \\
\hline & Male & $14(7.4)$ & $15(7.9)$ & $6(3.2)$ & $35(18.4)$ \\
\hline \multirow[t]{2}{*}{ I don't know } & Female & - & $10(5.3)$ & $8(4.2)$ & $18(9.5)$ \\
\hline & Male & - & $15(7.9)$ & $5(2.6)$ & $20(10.5)$ \\
\hline Total & & $26(13.7)$ & $94(49.5)$ & $70(36.8)$ & $190(100)$ \\
\hline
\end{tabular}

Table 4.1.6. How do They Cope with These Discriminatory Practices

\begin{tabular}{|c|c|c|c|c|c|}
\hline Statement & Variable & Old & Inter & New & Total \\
\hline \multirow[t]{2}{*}{ Look for Another Accommodation } & Female & $10(5.3)$ & $34(17.9)$ & $26(13.7)$ & $70(36.8)$ \\
\hline & Male & $2(1.1)$ & $10(5.3)$ & $18(9.5)$ & $30(15.8)$ \\
\hline \multirow[t]{2}{*}{ Succumb to these Practices } & Female & - & - & - & - \\
\hline & Male & - & - & - & - \\
\hline \multirow[t]{2}{*}{ Report to the University Authority } & Female & - & - & - & - \\
\hline & Male & - & - & - & - \\
\hline No Response & & $14(7.4)$ & $50(26.3)$ & $26(13.7)$ & \\
\hline Total & & $26(13.7)$ & $94(49.5)$ & $70(36.8)$ & $190(100)$ \\
\hline
\end{tabular}


Table 4.1.7. Disturbances Experienced at Home

\begin{tabular}{|c|c|c|c|c|c|}
\hline Statement & Variable & Old & Inter & New & Total \\
\hline \multirow[t]{2}{*}{ Domestic Violence } & Female & $2(1.1)$ & $16(8.4)$ & $16(8.4)$ & $34(17.9)$ \\
\hline & Male & $10(5.3)$ & $12(6.3)$ & $10(5.3)$ & $32(16.8)$ \\
\hline \multirow[t]{2}{*}{ Neighbours Disturbances } & Female & $8(4.2)$ & $22(11.6)$ & $20(10.5)$ & $50(26.3)$ \\
\hline & Male & $6(3.2)$ & $18(9.5)$ & $15(7.9)$ & $39(20.5)$ \\
\hline \multirow[t]{2}{*}{ Increase in House Rent } & Female & - & $13(6.8)$ & $5(3.2)$ & $18(9.5)$ \\
\hline & Male & - & - & - & - \\
\hline \multirow[t]{2}{*}{ Incidence of Robbery } & Female & - & $10(5.3)$ & - & $10(5.3)$ \\
\hline & Male & - & $3(1.6)$ & $4(2.1)$ & $7(3.7)$ \\
\hline \multirow[t]{2}{*}{ None of the above } & Female & - & - & - & - \\
\hline & Male & - & - & - & - \\
\hline Total & & $26(13.7)$ & $94(49.5)$ & $70(36.8)$ & $190(100)$ \\
\hline
\end{tabular}

4.1.8. Relationship between Landlords/Landladies and Students

\begin{tabular}{|c|c|c|c|c|c|}
\hline Statement & Variable & Old & Inter & New & Total \\
\hline Cordial & Female & - & $16(8.4)$ & $8(4.2)$ & $18(9.5)$ \\
\cline { 2 - 6 } & Male & $10(5.3)$ & $15(7.9)$ & $16(8.4)$ & $41(21.6)$ \\
\hline Conflictual & Female & $6(3.2)$ & $33(17.4)$ & $18(9.5)$ & $57(30)$ \\
\cline { 2 - 6 } & Male & - & $16(8.4)$ & $12(6.3)$ & $29(15.3)$ \\
\hline Indifference & Female & $4(2.1)$ & $4(2.1)$ & $10(5.3)$ & $18(9.5)$ \\
\cline { 2 - 6 } & Male & & $9(4.7)$ & - & $9(4.7)$ \\
\hline I don't know & Female & - & $7(3.7)$ & $5(2.6)$ & $12(6.3)$ \\
\cline { 2 - 6 } & Male & $6(3.2)$ & - & - & - \\
\hline Total & & $\mathbf{2 6 ( 1 3 . 7 )}$ & $\mathbf{9 4}(\mathbf{4 9 . 5 )}$ & $\mathbf{7 0 ( 3 6 . 8 )}$ & $\mathbf{1 9 0}(\mathbf{1 0 0})$ \\
\hline
\end{tabular}

Table 4.1.9. Challenges Faced as Non-Residential University Students

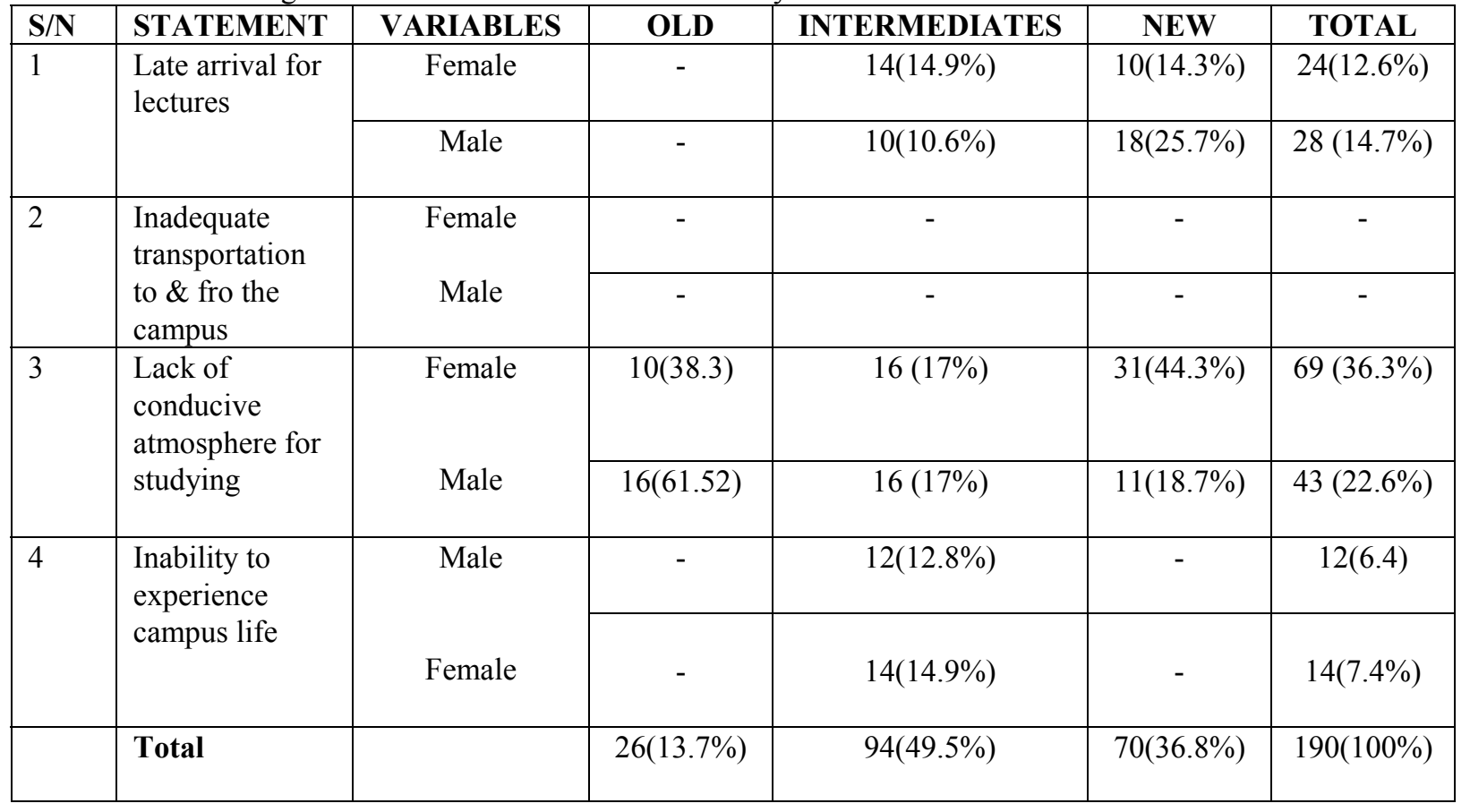




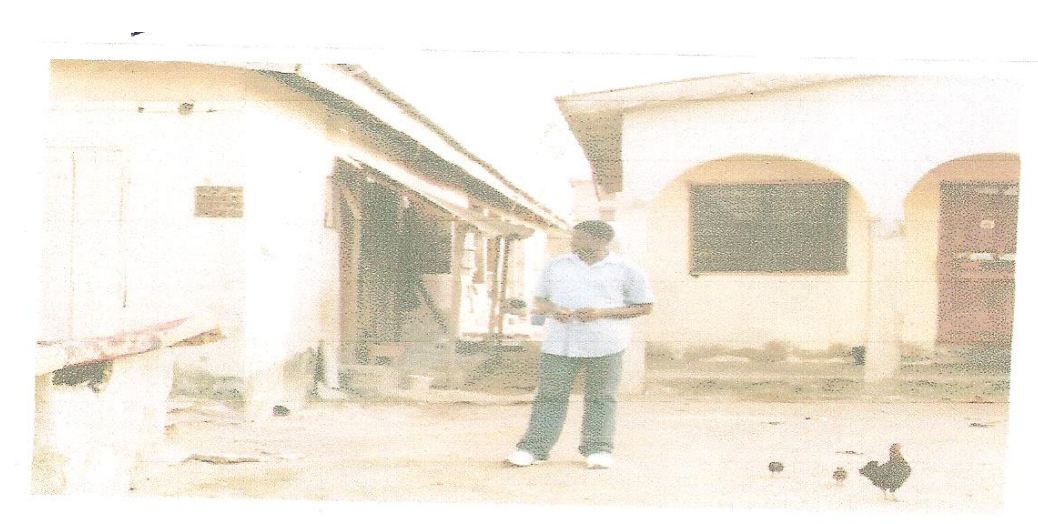

Picture 1. One of the intermediate students standing in front of his hostel in the LASU neighbourhood

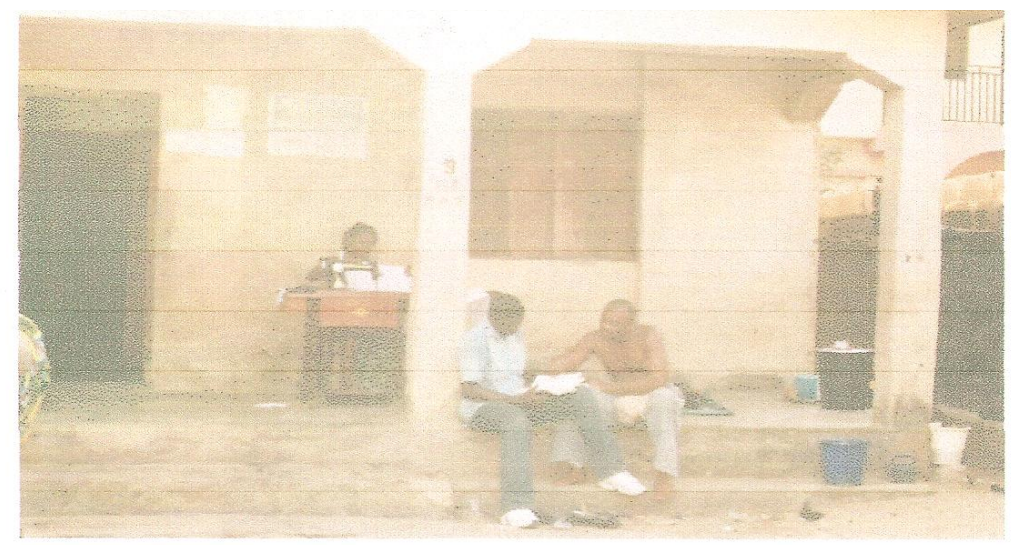

Picture 2. Two university students preparing for one of the semester's examination 


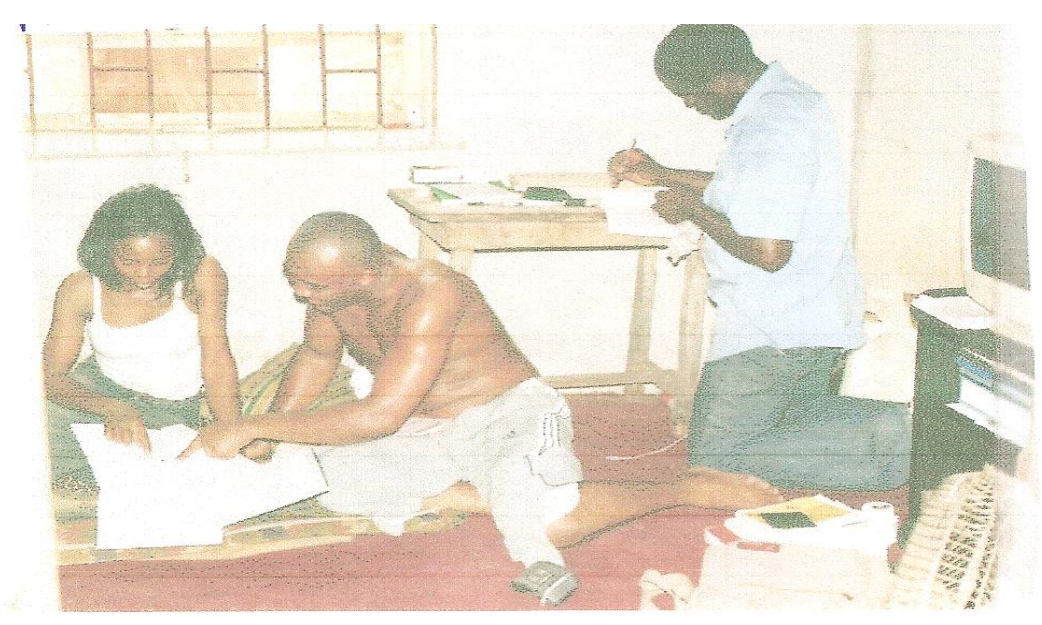

Picture 3. A scene of two third year and an intermediate students in one of the rooms in a residential hostel studying

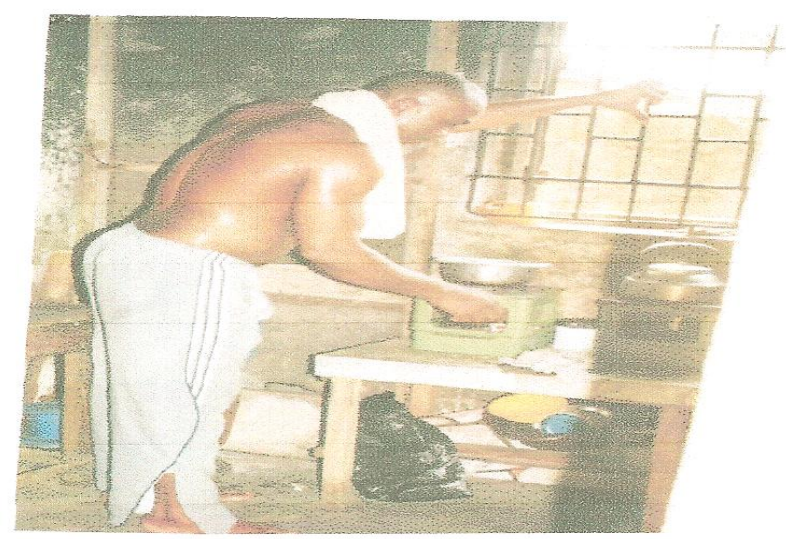

Picture 4. A kitchen scene showing a student 


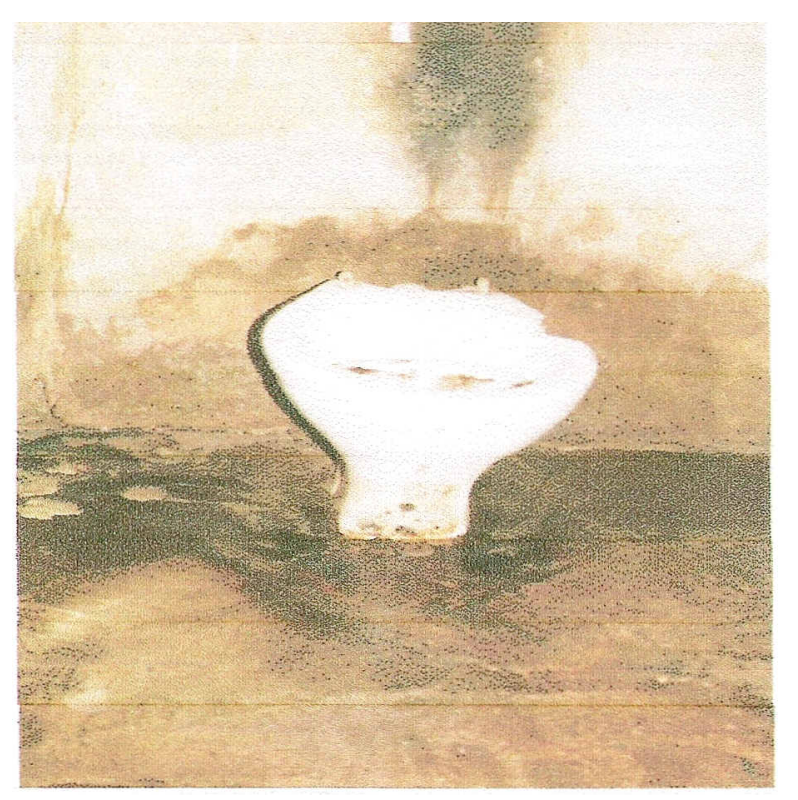

Picture 5. A toilet scene in one of the students' hostels 